\title{
Comparative study on the toxic mechanisms of medical nanosilver and silver ions on the antioxidant system of erythrocytes: from the aspects of antioxidant enzyme activities and molecular interaction mechanisms
}

\author{
Wenxu Fang ${ }^{1,3}$, Zhenxing Chi ${ }^{1,2,3^{*}}$, Weiguo $\mathrm{Li}^{1}$, Xunuo Zhang ${ }^{1}$ and Qiang Zhang ${ }^{1}$
}

\begin{abstract}
Background: The wide application of silver nanoparticles (AgNPs) in medicals and daily utensils increases the risk of human exposure. The study on cell and protein changes induced by medical AgNPs $(20 \mathrm{~nm})$ and $\mathrm{Ag}^{+}$gave insights into the toxicity mechanisms of them.

Results: AgNPs and $\mathrm{Ag}^{+}$affected the enzymatic and non-enzymatic antioxidant systems of red blood cells (RBCs). When RBCs were exposed to AgNPs or $\mathrm{Ag}^{+}(0-0.24 \mu \mathrm{g} / \mathrm{mL})$, catalase (CAT), superoxide dismutase (SOD) and glutathione peroxidase (GPX) were more sensitive to $\mathrm{Ag}^{+}$, whereas the RBCs had slightly higher glutathione (GSH) contents treated by AgNPs. Both AgNPs and $\mathrm{Ag}^{+}$increased the malondialdehyde (MDA) content of RBCs, but the difference was not significant. The difference in the change of the enzyme activity indicated that AgNPs and $\mathrm{Ag}^{+}$ have different influencing mechanisms on CAT and GPX. And SOD has stronger resistance to both of AgNPs and $\mathrm{Ag}^{+}$. When AgNPs or $\mathrm{Ag}^{+}(0-10 \mu \mathrm{g} / \mathrm{mL})$ was directly applied on enzymatic proteins, although $\mathrm{AgNPs}$ or $\mathrm{Ag}^{+}$at a high concentration was toxic, at the concentration below $0.4 \mu \mathrm{g} / \mathrm{mL}$ could promote the activities of CAT/SOD/GPX. The spectroscopic results (fluorescence, synchronous fluorescence, resonance light scattering and ultraviolet absorption), including the changes in amino acid microenvironment, peptide chain conformation, and aggregation state, indicated that the interaction mechanism and conformational changes were also the important factors for the changes in the activities of SOD/CAT when SOD/CAT were directly exposed to AgNPs or $\mathrm{Ag}^{+}$.
\end{abstract}

Conclusions: Low concentration $\left(<0.4 \mu \mathrm{g} / \mathrm{mL}\right.$ ) of AgNPs is relatively safe and the direct effects of AgNPs and $\mathrm{Ag}^{+}$on enzymes are important reasons for the change in antioxidant capacity of RBCs.

Keywords: Silver nanoparticles, Silver ions, Toxicity, Red blood cells, Antioxidant enzyme

\section{Introduction}

With the development of nanotechnology, nanosilver has been widely applied in industrial and biomedical products. Nanosilver is important for transparent conductive coatings in fabricating printed electronic devices such as

\footnotetext{
*Correspondence: zhenxingchi@gmail.com

${ }^{1}$ Department of Environmental Engineering, Harbin Institute of Technology, Weihai, 2\# Wenhua West Road, Weihai 264209, People's Republic of China

Full list of author information is available at the end of the article
}

flexible displays and solar cells due to its excellent conductivity and thermal conductivity [1]. The antibacterial activity of AgNPs is well known [2]. Therefore, AgNPs are applied in household appliances, toothpaste, and medical bandages to achieve antibacterial and anti-infection effects [3]. However, these applications resulted in the accumulation of AgNPs in the environment and organisms [4-9]. Due to these applications, residues and bioaccumulation of AgNPs have increased their exposure to human beings, thereby increasing the potential risks of toxicity [10]. 
AgNPs toxicity affected all kind of cells from bacteria to eukaryotes and even viruses [11]. AgNPs of certain concentrations about over $10 \mu \mathrm{g} / \mathrm{mL}$ have significant toxic effects on the proliferation of mammalian cells, such as human blood mononuclear cells [12], mesenchymal stem cells [13], human bronchial epithelial (BEAS-2B) cells [14], mouse vascular endothelial cells [15], spermatogonial stem cells [16], mouse embryonic fibroblast cell line and human breast carcinoma cell line [17]. AgNPs are also toxic to many species including HIV-1 [18], fish [1921], rabbit [22], halophilic microalgae [23], green freshwater algae [24], and Arabidopsis [25].

AgNPs themselves were toxic because of their size and shape or released silver ions, which are well known for their antibacterial and other destructive behaviors [26]. Durán et al. [27] concluded that the toxicity of AgNPs had three possible toxicity mechanisms. Firstly, free $\mathrm{Ag}^{+}$ uptaken by cells destroy the production of ATP and DNA replication. Secondly, the initiation of reactive oxygen species (ROS) is promoted on the surface of AgNPs and Ag ions. Thirdly, AgNPs directly damage cell membrane. The comparative study [9] on the toxicity of AgNPs and $\mathrm{Ag}^{+}$to Escherichia coli suggested that the release of bioavailable Ag ions from AgNPs promoted a higher toxicity. In addition, $10 \mu \mathrm{g} / \mathrm{mL}$ AgNPs treatment had toxic effects on the early growth of wheat seedlings and the AgNPs effects observed were primarily ascribed to Ag ions released by oxidative dissolution at the root interface in the presence of secreted root metabolites [28]. The marine microalgae $D$. salina were also found to be more sensitive to Ag ions than AgNPs [23]. However, Greulich et al. [29] reported that the effective toxic concentrations of AgNPs and $\mathrm{Ag}^{+}$towards bacteria and human cells were almost the same.

Many toxic effects of AgNPs on RBCs (from common carp [30], Mus musculus [31], rats [32, 33], and human [34]) have been reported. The cytotoxicity of AgNPs on RBCs was ascribed [35] to the direct interaction between nanoparticles and RBCs, which resulted in the production of oxidative stress, membrane injury, and subsequent hemolysis. However, the comparative study on the toxicity of silver nanoparticles and silver ions to RBCs was seldom reported.

As the main function, oxygen transport causes RBCs to be exposed to a significant dose of continuous oxidative stress [36]. Therefore, antioxidants systems are important for the RBCs. Yet the toxicity mechanism of AgNPs is unclear and whether AgNPs are more toxic than $\mathrm{Ag}^{+}$to the antioxidant capacity of human red blood cells should be further confirmed. This study explores the effects of AgNPs and $\mathrm{Ag}^{+}$on the antioxidant capacity of red blood cells and the activities and structures of several key antioxidant enzymes. The study gives insights into the toxicity mechanism of AgNPs and $\mathrm{Ag}^{+}$and provides basic data for their application and environmental protection.

\section{Materials and methods \\ Reagents and apparatus}

EDTA-K $K_{2}$ (Tianjin Kermel Chemical Reagent Co., Ltd.) stabilized blood samples were obtained from the Weihai Blood Centre in China (Ethics statement: The study was approved by the Ethics Committee of Weihai Blood Centre). AgNPs with an average diameter of $20 \mathrm{~nm}$ was purchased from Nanjing/Jiangsu XFNANO Materials Tech Co., Ltd. $\left(\mathrm{NH}_{4}\right)_{2} \mathrm{SO}_{4}, \mathrm{NaOH}, \mathrm{NaCl}$ and $\mathrm{AgNO}_{3}$ was purchased from Sinopharm Chemical Reagent Co., Ltd. The $\mathrm{pH}$ of phosphate buffer saline (PBS) is 7.4. The silver solutions were preserved in the dark at room temperature and diluted to different concentrations as required. PBS, SOD $(\mathrm{Cu} / \mathrm{Zn}-\mathrm{SOD}$, from bovine RBCs) and CAT (from bovine liver) were purchased from Beijing Biodee Biotechnology Co., Ltd. GPX was extracted from human RBCs [37] with ammonium sulfate precipitation method and purified by ion exchange chromatography with DEAE cellulose (DEAECrystarose Fast Flow, Wuhan Jing Cheng Bio Technology Co. Ltd.). Ultrafiltration centrifugal tubes (15KD, Millipore) were used to concentrate GPX and desalination. Bicinchoninic acid protein assay kit and GPX activity kit (Nanjing Jiancheng Bioengineering Institute) were used to detect the concentration and activity of purified GPX.

UV-visible absorption spectra were measured with a U-2910 spectrophotometer (Hitachi, Japan). Centrifugation of samples was performed with a CR21N HighSpeed Refrigerated Centrifuge (Hitachi, Japan). A digital dry bath incubator (HB-100, Hangzhou Bioer Technology Co., Ltd) was used to control the temperature. Fluorescence measurements were performed with a F2700 fluorescence spectrometer (Hitachi, Japan).

\section{Cytotoxicity of AgNPs and $\mathrm{Ag}^{+}$to RBCs}

The activities or contents of typical biomolecules were determined according to our previous methods [38]. In brief, the fresh blood sample was washed, diluted and mixed with different concentrations of AgNPs or $\mathrm{Ag}^{+}$. After incubated at $37{ }^{\circ} \mathrm{C}$ for $2 \mathrm{~h}$, PBS in the mixed solution was replaced by ultrapure water to achieve hemolysis. The hemolytic blood samples were used to measure the antioxidant defence capacity of RBCs by the detection kits (Nanjing Jiancheng Bioengineering Institute), namely, the relative activities or contents of CAT, SOD, GPX, GSH [2-nitrobenzoic acid (DTNB) method] and MDA [thiobarbituric acid (TBA) method]. The experimental data were expressed as mean $\pm \mathrm{SD}$ (standard deviation). 
Effects of AgNPs and $\mathrm{Ag}^{+}$on the activity of CAT/SOD/GPX at molecular level

A certain amount of PBS buffer solution (pH 7.4), CAT/ SOD/GPX storage liquid, different amounts of ultrapure water, and AgNPs or $\mathrm{Ag}^{+}$solution were added into tubes. After mixing, the solutions were kept away from light for $30 \mathrm{~min}$ at room temperature. After the reaction was completed, the enzyme activity in each tube was determined by corresponding kits. The brief descriptions of the methods are as follows: (1) Superoxide radical anion $\left(\mathrm{O}_{2}^{-} \cdot\right)$ generated from the xanthine and xanthine oxidase system can oxidize hydroxylamine to nitrite which causes absorbance at $550 \mathrm{~nm}$. The SOD in the samples can catalyse the $\mathrm{O}_{2}^{-}$. and lead to the reduction of nitrite, therefore reduced the colorimetric signal. (2) CAT can catalyse $\mathrm{H}_{2} \mathrm{O}_{2}$ into $\mathrm{H}_{2} \mathrm{O}$ and $\mathrm{O}_{2}$, which could be terminated by adding ammonium molybdate. Then the rest of $\mathrm{H}_{2} \mathrm{O}_{2}$ and ammonium molybdate produced a yellow complex which could be measured at $405 \mathrm{~nm}$. (3) GPX can catalyse the reaction of $\mathrm{H}_{2} \mathrm{O}_{2}$ with $\mathrm{GSH}$ to $\mathrm{H}_{2} \mathrm{O}$ and oxidized glutathione (GSSG). The activity of GPX was determined by measuring the consumption of GSH in the reaction.

\section{Effects of AgNPs and $\mathrm{Ag}^{+}$on the molecular structure of CAT/SOD}

\section{Fluorescence measurements and synchronous fluorescence}

The excitation wavelength $\left(\lambda_{\mathrm{ex}}\right)$ range, the emission wavelength $\left(\lambda_{e m}\right)$ range, the concentrations of CAT/ SOD and AgNPs $/ \mathrm{Ag}^{+}$and $\mathrm{pH}$ are shown in Figs. 3, 4 and 5 . The slit width was $5 \mathrm{~nm}$ and the voltage was $400 \mathrm{~V}$.

\section{Resonance light scattering measurements}

Resonance light scattering (RLS) was measured at $\lambda_{\mathrm{ex}}=\lambda_{\mathrm{em}}$ from 220 to $700 \mathrm{~nm}$. The RLS spectra of CAT/ SOD-AgNPs, CAT/SOD- $\mathrm{Ag}^{+}, \mathrm{CAT} / \mathrm{SOD}, \mathrm{AgNPs}$ and $\mathrm{Ag}^{+}$solution were measured to identify whether the AgNPs $/ \mathrm{Ag}^{+}$and CAT/SOD molecules were well mixed in the solution [39].

\section{UV-visible absorption spectra}

The UV-visible absorption spectra in the range of 190-300 $\mathrm{nm}$ was determined with the samples in $1.0 \mathrm{~cm} \times 1.0 \mathrm{~cm}$ quartz cuvettes $(\mathrm{T}=298 \mathrm{~K}$ and $\mathrm{pH} 7.4)$.

\section{Results and discussion}

\section{Effects of AgNPs and $\mathrm{Ag}^{+}$on typical biomolecules of RBCs}

The enzymatic antioxidant system (CAT, SOD and GPX) of RBCs is important for cellular biochemical functionality. The balance of these three enzymes is related with the antioxidant function [40]. Figure 1a-c show the effects of AgNPs and $\mathrm{Ag}^{+}$on the relative activities of CAT, SOD and GPX, respectively. When
$\mathrm{Ag}^{+}$concentration increased from 0 to $1.2 \times 10^{-7} \mathrm{~g} /$ $\mathrm{mL}$, the relative activities of CAT and SOD increased to $115 \%$ and $158 \%$, thus enhancing the degradation of hydrogen peroxide [41] and the removal of superoxide anion radical [42]. When $\mathrm{Ag}^{+}$concentration further increased to $2.6 \times 10^{-7} \mathrm{~g} / \mathrm{mL}$, the relative activities of CAT and SOD decreased may due to the binding of metal ions with biomolecules [43], but the relative activities of CAT and SOD were still greater than $100 \%$. With the increase in AgNPs concentration, the relative activity of CAT increased gradually, whereas the relative activity of SOD largely increased to $160 \%$ and was then maintained at the high level. When AgNPs or $\mathrm{Ag}^{+}$ concentration increased from 0 to $2.4 \times 10^{-7} \mathrm{~g} / \mathrm{mL}$, the relative activities of GPX decreased to $94 \%$ and $91 \%$, respectively. The decrease in GPX activity reduced the reaction of GSH with hydrogen peroxide [44].

The non-enzymatic antioxidant system also contributes to the defence of oxidative damage of cells. GSH is a typical non-enzymatic antioxidant maintaining the redox balance of RBCs [45, 46]. Figure $1 \mathrm{~d}$ shows that both AgNPs and $\mathrm{Ag}^{+}$affect the contents of GSH of RBCs. With the increase in the concentrations of AgNPs and $\mathrm{Ag}^{+}$, the contents of GSH in RBCs firstly increased and then became relatively stable. The content of GSH in RBCs treated with AgNPs was higher than that in $\mathrm{RBCs}$ treated with $\mathrm{Ag}^{+}$. The MDA is produced from lipid peroxidation after oxidative injury and its content indicates the oxidative stress level of RBCs [47]. As shown in Fig. 1e, in the concentration range of $0.3 \times 10^{-7}$ to $2.6 \times 10^{-7} \mathrm{~g} / \mathrm{mL}$, both AgNPs and $\mathrm{Ag}^{+}$ can cause the oxidative injury and increase the relative MDA content, but the difference is not significant.

Overall, the effects of AgNPs and $\mathrm{Ag}^{+}$on the activities of antioxidant enzymes or the content of GSH were different. However, both AgNPs and $\mathrm{Ag}^{+}$could result in oxidative injury (increased MDA content) to the similar degree.

\section{Direct effects of AgNPs and $\mathrm{Ag}^{+}$on the activities of CAT/ SOD/GPX}

The effects of AgNPs or $\mathrm{Ag}^{+}$on the activities of the antioxidant enzymes may rely on the direct action of AgNPs or $\mathrm{Ag}^{+}$on protein molecules. The effects of different doses of AgNPs or $\mathrm{Ag}^{+}$on the activities of antioxidant enzymes in vitro were investigated to validate above interpretation on the effects of AgNPs or $\mathrm{Ag}^{+}$. The experimental results are illustrated in Fig. 2.

Under the low concentration of AgNPs $\left(0-1.0 \times 10^{-7} \mathrm{~g} /\right.$ $\mathrm{mL})$ or $\mathrm{Ag}^{+}\left(0-2.0 \times 10^{-7} \mathrm{~g} / \mathrm{mL}\right)$, which is similar to the cell exposure level, the relative activity of CAT was increased by 7\% with the increase in $\mathrm{AgNPs}$ or $\mathrm{Ag}^{+}$concentration (Fig. 2a, b). The results were consistent with 
the results in the exposure at cell level. With the continuous increase in AgNPs concentration $\left(1.0 \times 10^{-7} \mathrm{~g} /\right.$ $\mathrm{mL}$ to $2.0 \times 10^{-7} \mathrm{~g} / \mathrm{mL}$ ), the relative activity of CAT began to decrease, but it was still greater than $100 \%$. With the continuous increase in AgNPs concentration (from $6.0 \times 10^{-7}$ to $1.0 \times 10^{-5} \mathrm{~g} / \mathrm{mL}$ ) or $\mathrm{Ag}^{+}$concentration (from $2.0 \times 10^{-7}$ to $1.0 \times 10^{-5} \mathrm{~g} / \mathrm{mL}$ ), the activity of CAT began to be inhibited and the relative activity finally decreased to $63 \%$ and $56 \%$, respectively. The degree of the decline of CAT activity caused by $\mathrm{Ag}^{+}$was larger than that caused by AgNPs.

When the concentration of AgNPs or $\mathrm{Ag}^{+}$increased under the low concentration $\left(0-1.0 \times 10^{-6} \mathrm{~g} / \mathrm{mL}\right)$, the relative activity of SOD increased to about $110 \%$ and the degree of variability was the same (Fig. 2c, d). The results were consistent with the results in the exposure at cell level. SOD activity was not inhibited until the concentration of AgNPs was increased above $8.0 \times 10^{-6} \mathrm{~g} / \mathrm{mL}$. As the concentration increased (from $1.0 \times 10^{-6}$ to $\left.1.0 \times 10^{-5} \mathrm{~g} / \mathrm{mL}\right), \mathrm{Ag}^{+}$continued to promote SOD relative activity from 109 to $184 \%$, whereas AgNPs promoted SOD relative activity to decrease from 107 to $98 \%$. Under the higher $\mathrm{Ag}^{+}$concentration (from $1.0 \times 10^{-6}$ to $1.0 \times 10^{-5} \mathrm{~g} / \mathrm{mL}$ ), $\mathrm{Ag}^{+}$had the greater influence on SOD activity than AgNPs. The results were opposite to the results in the exposure at cell level. The causes for the opposite results remained to be further explored. We speculate that the reason for the opposite results may be that cell membranes has a protective effect for cell-level exposure compared with direct enzyme exposure, and AgNPs have different with $\mathrm{Ag}^{+}$in the penetration through cell membranes. However, under the similar concentration of AgNPs or $\mathrm{Ag}^{+}$, the changing trend of SOD relative activity at enzyme level was similar to that at cell level.

Compared with $\mathrm{Ag}^{+}$, AgNPs had the stronger effect on GPX activity (Fig. 2e, f). When AgNPs concentration was greater than $8.0 \times 10^{-7} \mathrm{~g} / \mathrm{mL}$, GPX activity began to be inhibited. When the $\mathrm{Ag}^{+}$concentration was greater than $1.6 \times 10^{-6} \mathrm{~g} / \mathrm{mL}$, GPX activity began to be inhibited. When the concentration of AgNPs increased from $8.0 \times 10^{-7}$ to $12.8 \times 10^{-6} \mathrm{~g} / \mathrm{mL}$, the GPX relative activity decreased from 98 to $54 \%$. When the concentration of $\mathrm{Ag}^{+}$increased from $1.6 \times 10^{-6}$ to $12.8 \times 10^{-6} \mathrm{~g} / \mathrm{mL}$, the GPX relative activity decreased from 100 to $88 \%$. With the increase in the concentration of $\mathrm{Ag}^{+}$or AgNPs, the decreasing degree of GPX activity caused by AgNPs was significantly greater than that caused by $\mathrm{Ag}^{+}$. We speculated that the direct interaction of AgNPs or $\mathrm{Ag}^{+}$with GPX might lead to the change in its activity, which was one of the reasons for the decrease in erythrocyte GPX activity caused by AgNPs and $\mathrm{Ag}^{+}$.
In brief, the influences of AgNPs on the activities of CAT, SOD and GPX in vitro were different from those of $\mathrm{Ag}^{+}$on their activities. The difference in the cell membrane permeation ability of AgNPs and $\mathrm{Ag}^{+}$may led to the difference in their effects on the enzyme activities of RBCs. However, under similar exposure concentrations, the influences of AgNPs or $\mathrm{Ag}^{+}$on the CAT, SOD and GPX activities at cellular and molecular levels showed certain similarity. We deduced that the direct interaction between molecules (AgNPs/ $\mathrm{Ag}^{+}$and CAT/SOD/GPX) was one of the important reasons for the change in the antioxidant enzyme activity of RBCs.

\section{Influences of AgNPs and $\mathrm{Ag}^{+}$on the fluorescence intensity of CAT/SOD}

In general, most proteins [48-50] have the intrinsic fluorescence due to tryptophan (Trp), tyrosine (Tyr) and phenylalanine (Phe) residues. The intrinsic fluorescence of most proteins is mainly ascribed to Trp and Tyr residues since Phe residue has a low quantum [51, 52]. The fluorescence quenching of protein caused by certain particles can reflect the degree of binding and binding mechanism between these particles and proteins [53]. The fluorescence quenching of SOD [54] and CAT [55] caused by the increase in AgNPs concentration should be ascribed to dynamic quenching. $\mathrm{Ag}^{+}$was also a strong quencher of ovalbumin fluorescence and the complexes of $\mathrm{Ag}^{+}$ with sulfhydryl compounds also generated mercaptide absorption bands capable of quenching indole fluorescence by the energy transfer mechanism [56]. The fluorescence quenching of bovine serum albumin by $\mathrm{Ag}^{+}$is a dynamic quenching process with two binding modes: a strong one under low $\mathrm{Ag}^{+}$concentration and a weak one under high $\mathrm{Ag}^{+}$concentration [57].

The intrinsic fluorescence spectra of CAT/SOD under different concentrations of AgNPs and $\mathrm{Ag}^{+}$are shown in Fig. 3. The addition of AgNPs or $\mathrm{Ag}^{+}$did not significantly change the peak position of CAT fluorescence spectra. However, with the increase in the concentrations of AgNPs and $\mathrm{Ag}^{+}$, the fluorescence intensity of CAT decreased regularly, indicating that they had a quenching effect on the endogenous fluorescence of CAT.

AgNPs caused a slight blue shift in the peak position of SOD fluorescence emission spectrum, indicating that the increased hydrophobicity of fluorescent groups and the decreased polarity. It was speculated that the polarity of the main source of endogenous fluorescence (tryptophan and tyrosine residues) was changed. The addition of $\mathrm{Ag}^{+}$ did not lead to the significant peak shift of SOD. With the increase in the concentrations of AgNPs and $\mathrm{Ag}^{+}$, both of them had the quenching effect on the endogenous fluorescence of SOD. The quenching effect of $\mathrm{Ag}^{+}$on the intrinsic fluorescence of CAT was stronger than that of 

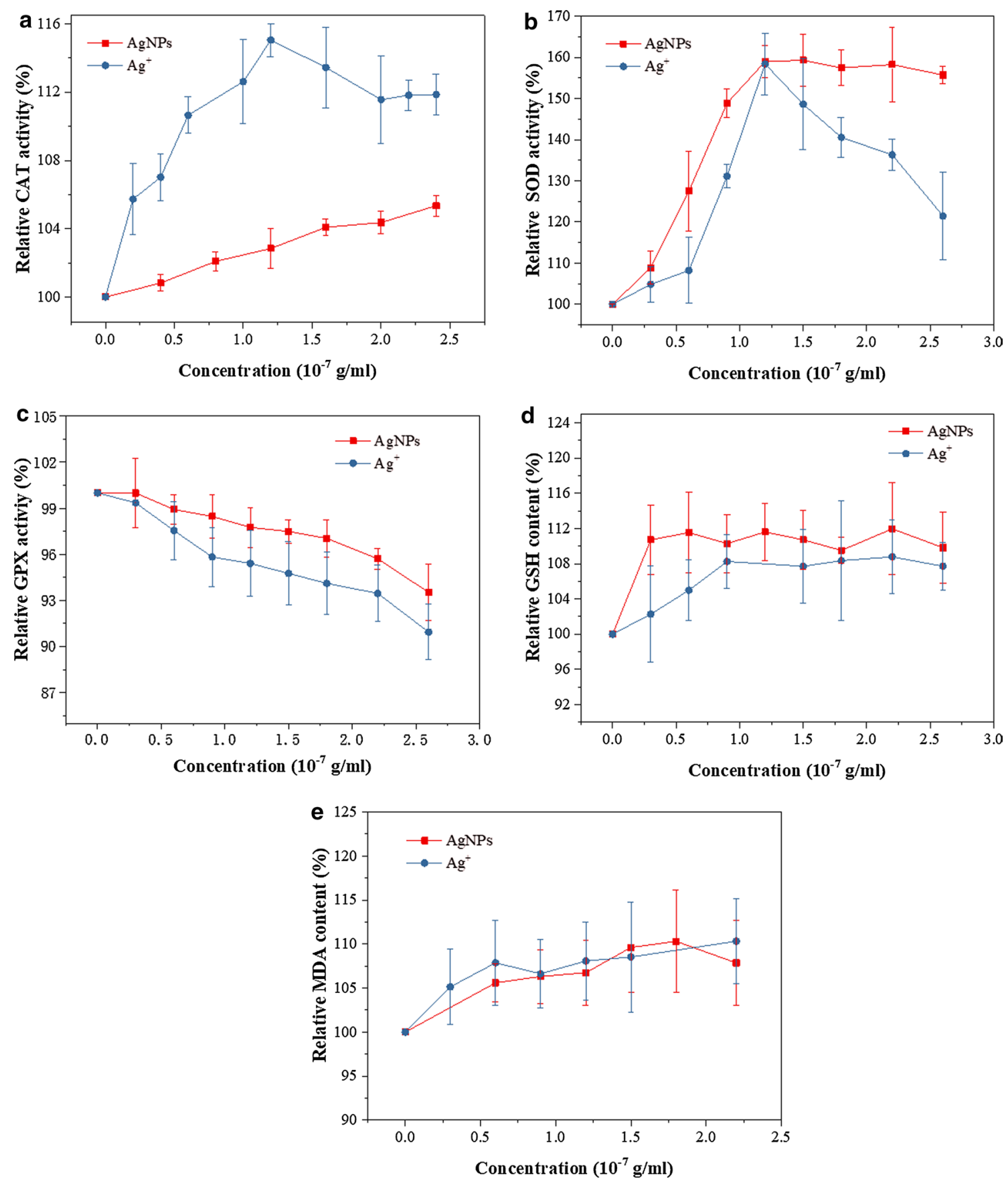

Fig. 1 The change of relative activities or contents of CAT (a), SOD (b), GPX (c), GSH (d) and MDA (e) of RBCs with increasing the concentrations of AgNPs and $\mathrm{Ag}^{+}$

AgNPs, whereas the quenching effect of AgNPs on the intrinsic fluorescence of SOD was stronger than that of $\mathrm{Ag}^{+}$.

Compared with AgNPs, $\mathrm{Ag}^{+}$could be bound to CAT with higher affinity. Therefore, the decrease in CAT activity caused by the increase in $\mathrm{Ag}^{+}$concentration was more significant than that caused by the increase in AgNPs concentration. Compared with $\mathrm{Ag}^{+}$, AgNPs could be bound to SOD with higher affinity. The difference was the reason that the increase in AgNPs concentration led to the decrease in SOD activity, whereas the increase in $\mathrm{Ag}^{+}$ 

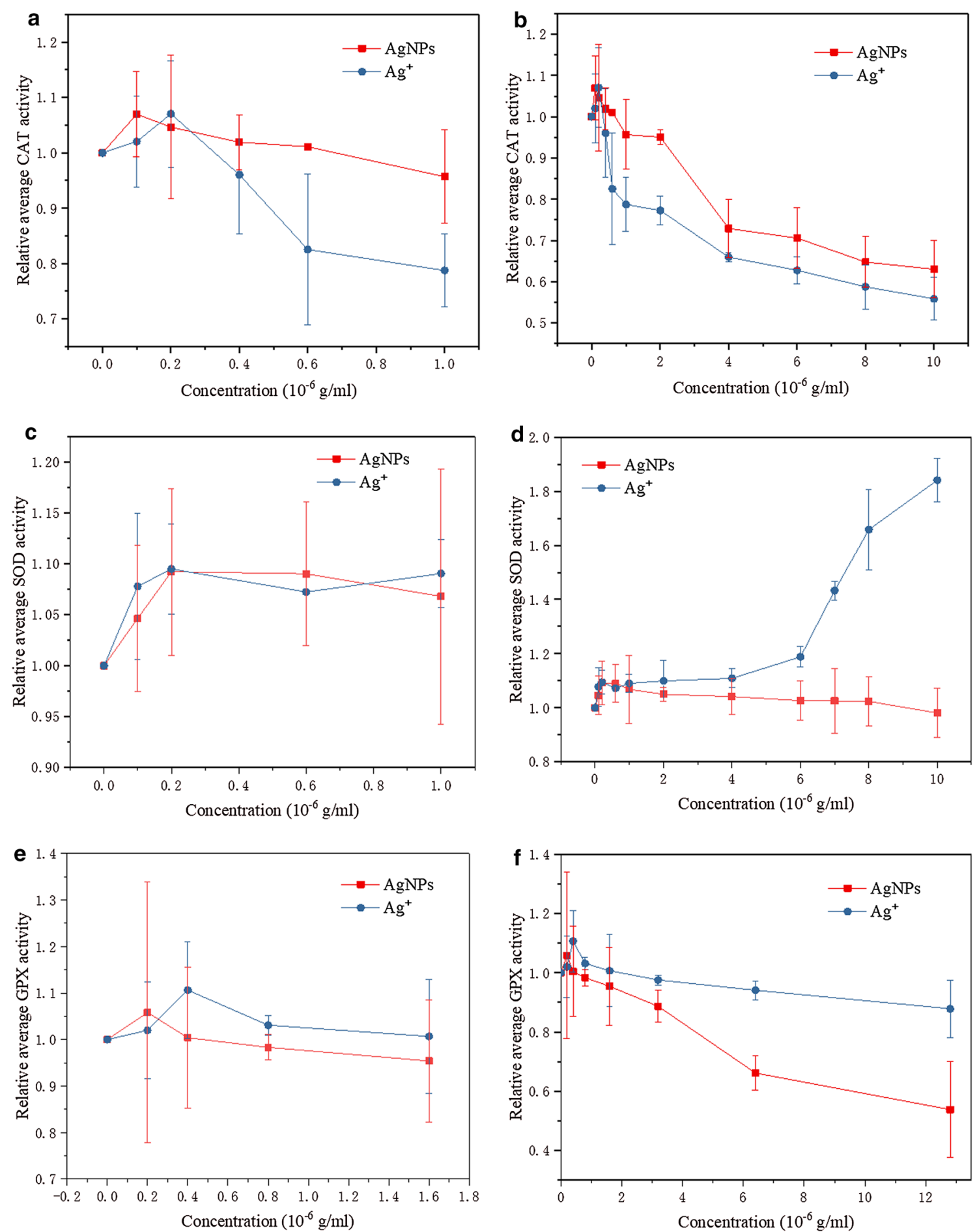

Fig. 2 The activity of CAT $(\mathbf{a}, \mathbf{b})$, SOD $(\mathbf{c}, \mathbf{d})$ and GPX $(\mathbf{e}, \mathbf{f})$ in the presence of AgNPs or $\mathrm{Ag}^{+}$at different concentrations. Condition: $\mathrm{pH} 7.4, \mathrm{~T}=298 \mathrm{~K}$, $C(C A T)=2 \times 10^{-7} \mathrm{~mol} / \mathrm{L}, C(S O D)=2 \times 10^{-7} \mathrm{~mol} / \mathrm{L}, C(G P X)=1.6 \times 10^{-6} \mathrm{~mol} / \mathrm{L}$ 


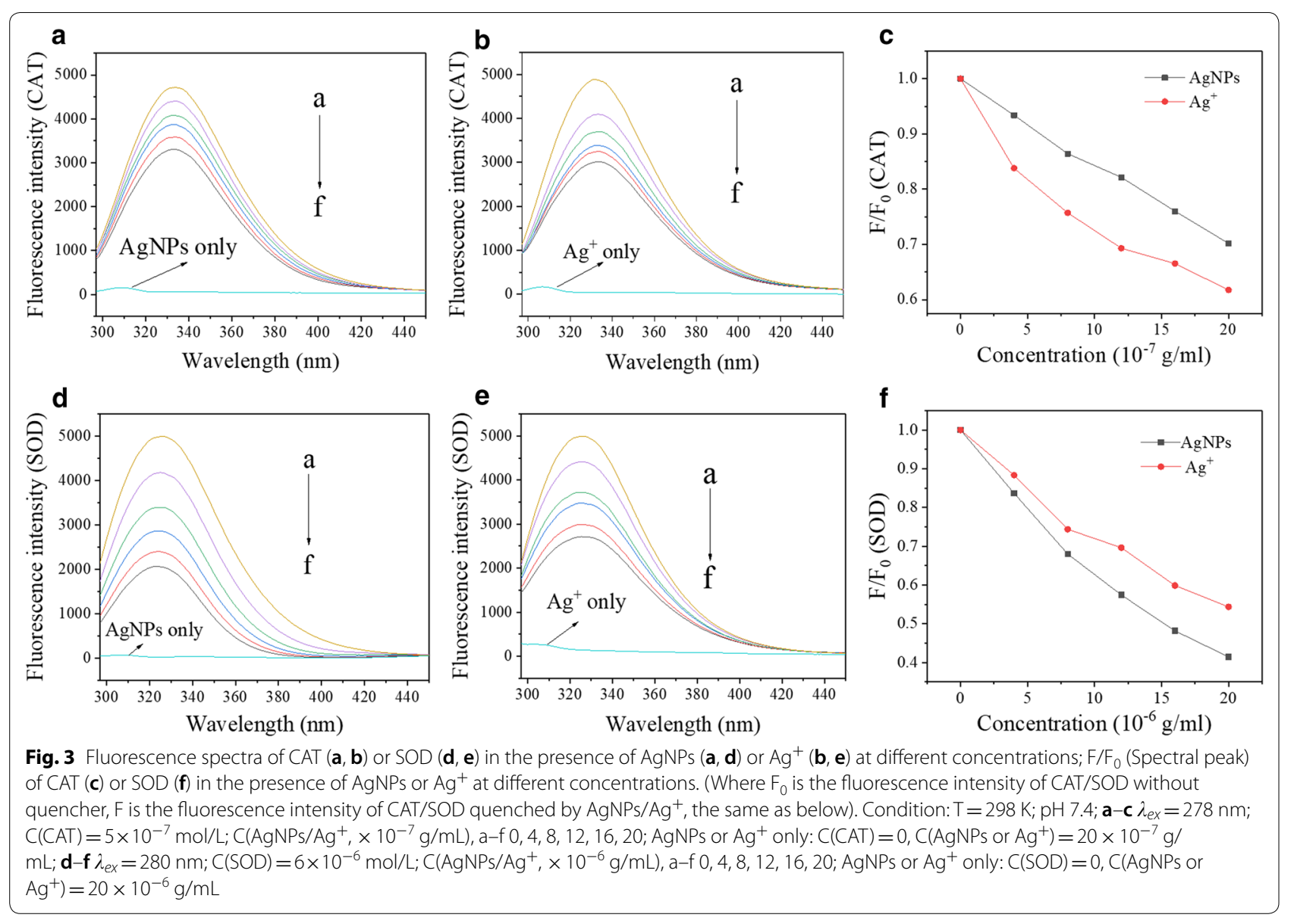

concentration enhanced the SOD activity, when AgNPs or $\mathrm{Ag}^{+}$was directly applied on enzymatic proteins.

\section{Influences of AgNPs and $\mathrm{Ag}^{+}$on the microenvironment of CAT}

The synchronous spectra obtained at $\Delta \lambda=15 \mathrm{~nm}$ showed the spectral characteristics of Tyr, whereas the synchronous fluorescence spectra at $\Delta \lambda=60 \mathrm{~nm}$ showed the spectral characteristics of $\operatorname{Trp}[58,59]$. Synchronous fluorescence spectra can be used to investigate the effects of molecules on protein conformation and detect the microenvironment of endogenous fluorescent amino acid residues in proteins [60]. With the increase in the concentration of AgNPs or $\mathrm{Ag}^{+}$, the fluorescence intensity of Trp was decreased (Fig. $4 \mathrm{a}-\mathrm{c}$ ). At the same time, there was no obvious red shift or blue shift in the position of fluorescence emission peaks, indicating that neither AgNPs nor $\mathrm{Ag}^{+}$could significantly change the microenvironment of CAT tryptophan residues.

Figure $4 \mathrm{~d}$ shows the changes in the microenvironment of tyrosine residues caused by the addition of AgNPs. With the increase in AgNPs concentration, the position of the fluorescence emission peak of tyrosine residues showed a slight blue shift, indicating that AgNPs slightly changed the CAT tyrosine residue microenvironment and enhanced the hydrophobicity.

Figure $4 \mathrm{e}$ shows the changes in the microenvironment of tyrosine residues caused by the addition of $\mathrm{Ag}^{+}$. With the increase in $\mathrm{Ag}^{+}$concentration, the fluorescence intensity firstly decreased and then increased. It was reported that $\mathrm{Ag}^{+}$could react with 6-mercaptopurine to form highly fluorescent complexes under similar conditions ( $\mathrm{pH}$ 7.2) [61]. Also the existing literature indicated that tryptophan could interact with gold nanorods and lead to enhancement in fluorescence intensity [62]. It was speculated that the increase in the fluorescence intensity was ascribed to highly fluorescent complexes generated in the reaction between high concentration of $\mathrm{Ag}^{+}$and CAT. The reaction made protein molecules contract, thus enhancing energy transfer among amino acids as well as the fluorescence intensity [63]. The fluorescence emission peaks of CAT tyrosine residues were slightly redshifted. The addition of $\mathrm{Ag}^{+}$weakened the hydrophobicity and enhanced the polarity of CAT tyrosine residues.

Although the influences of $\mathrm{Ag}^{+}$and AgNPs on CAT were different (positive effect or negative effect), 


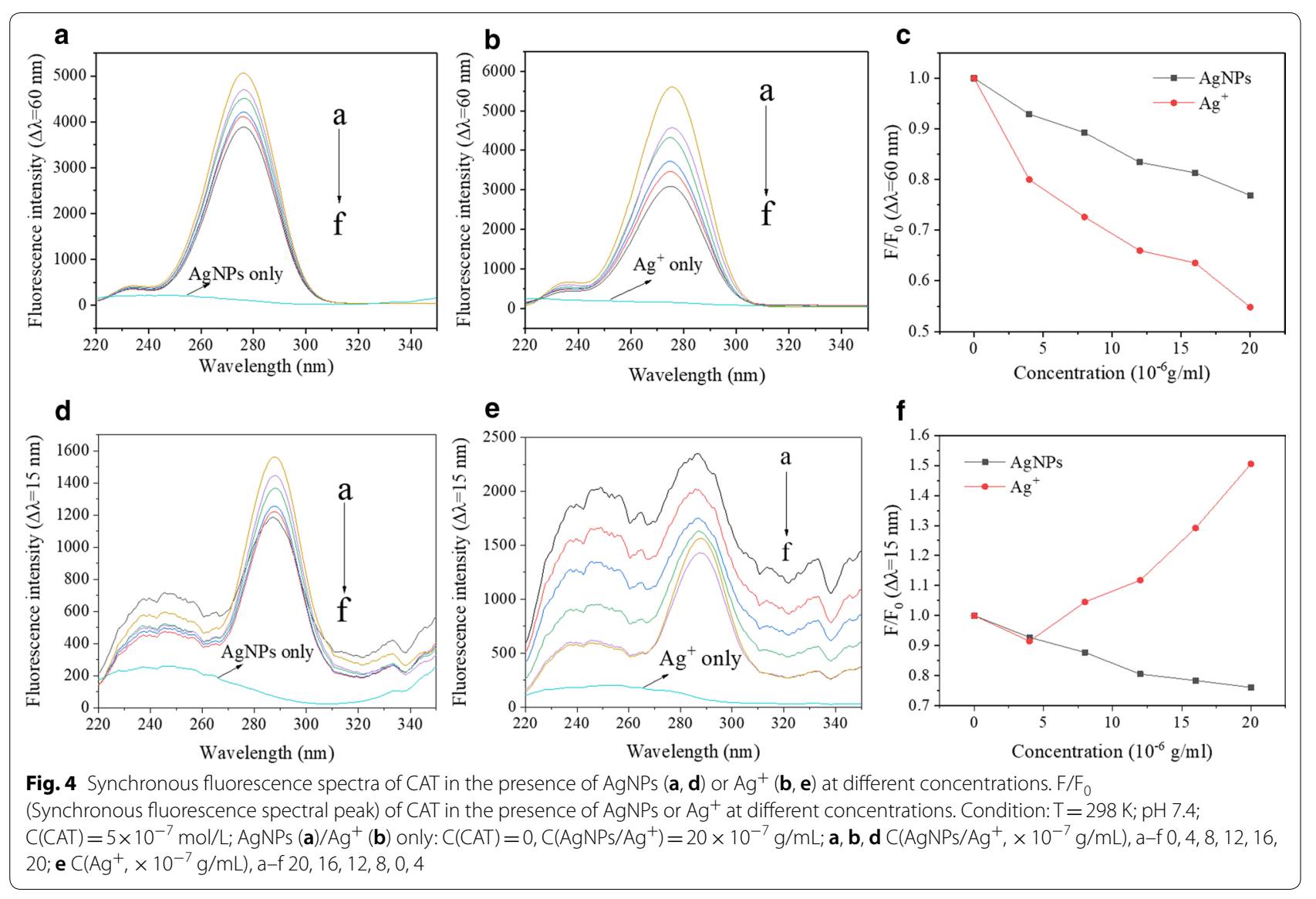

compared with AgNPs, $\mathrm{Ag}^{+}$had a stronger effect on the fluorescence change in tryptophan residues and tyrosine residues of CAT, thus leading to the stronger inhibition of $\mathrm{Ag}^{+}$on enzyme activity at higher $\mathrm{Ag}^{+}$concentrations.

\section{Influences of AgNPs and $\mathrm{Ag}^{+}$on the microenvironment of SOD}

The addition of AgNPs resulted in a slight blue shift in the position of SOD fluorescence peak (Fig. $5 \mathrm{a}-\mathrm{c}$ ), indicating that AgNPs enhanced the hydrophobicity and weakened the polarity of SOD tryptophan residues in the microenvironment. $\mathrm{Ag}^{+}$did not cause a significant shift in the peak position, indicating that $\mathrm{Ag}^{+}$did not cause a significant change in the microenvironment polarity of tryptophan residues.

With the increase in AgNPs concentration, the position of the fluorescence emission peak of the tyrosine residues did not move obviously (Fig. 5d), indicating that AgNPs did not significantly change the tyrosine residue microenvironment. It was found that with the increase in $\mathrm{Ag}^{+}$concentration, the position of the fluorescence emission peak was blue-shifted, indicating that $\mathrm{Ag}^{+}$could change the conformation of SOD, thus increasing the hydrophobicity of the SOD tyrosine residue microenvironment. The fluorescence intensity of SOD tyrosine residues decreased with the addition of the low concentration of $\mathrm{Ag}^{+}$(Fig. 5e). When the concentration of $\mathrm{Ag}^{+}$further increased to $8 \times 10^{-6} \mathrm{~g} /$ $\mathrm{mL}$, the same trend to CAT activity was observed (the dotted line in Fig. 5f). The fluorescence intensity firstly decreased and then increased with the increase in $\mathrm{Ag}^{+}$ concentration. The result might be ascribed to the formation of highly fluorescent complexes [61] between $\mathrm{Ag}^{+}$and SOD and the binding site was tyrosine residues of SOD.

Synchronous fluorescence spectra showed that the quenching effect of AgNPs on tryptophan residue fluorescence of SOD was stronger than that of $\mathrm{Ag}^{+}$. Moreover, $\mathrm{Ag}^{+}$did not change the microenvironment of tryptophan residues, whereas AgNPs enhanced the hydrophobicity and weakened the polarity of SOD tryptophan residues. Under a low concentration $\left(0-4 \times 10^{-6} \mathrm{~g} / \mathrm{mL}\right)$, the effect of AgNPs on the fluorescence quenching of SOD tyrosine residues was stronger than that of $\mathrm{Ag}^{+}$. These results were consistent with the inhibition of SOD activity caused by a high concentration of AgNPs. 


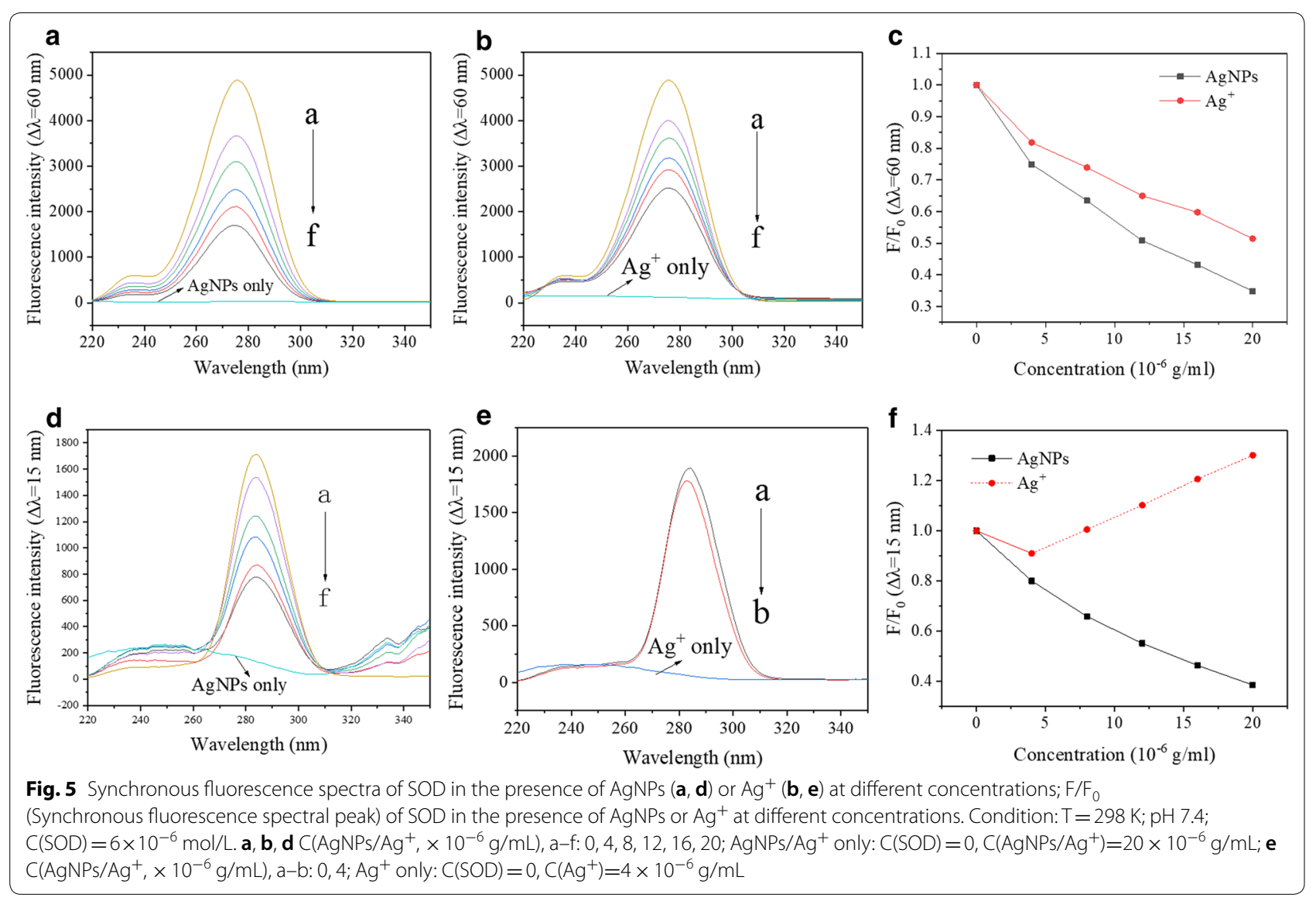

\section{Aggregation state of AgNPs and $\mathrm{Ag}^{+}$with CAT/SOD}

RLS experiments are usually used to explore the aggregation state between materials. For aggregated species, enhanced light scattering can be observed in the wavelength characteristics of these species [39] The RLS of CAT near $350 \mathrm{~nm}$ was strong, whereas the intensity of $\mathrm{Ag}^{+}$peak near $350 \mathrm{~nm}$ was weak under the experimental conditions (Fig. 6a). The RLS intensity of CAT $-\mathrm{Ag}^{+}$ was higher than that of $\mathrm{CAT}$ and $\mathrm{Ag}^{+}$, indicating that the formation of CAT-AgNPs aggregates increased the average particle diameter. The RLS intensity of CAT-AgNPs mixed system was lower than that of AgNPs or CAT (Fig. 6b). The results showed that polymerization did not occur between AgNPs and CAT and that the CATAgNPs system became more uniform without increasing the particle size.

At $314 \mathrm{~nm}$, the RLS intensity of $\mathrm{Ag}^{+}$was strong and the intensity of SOD was weak. The RLS intensity of $\mathrm{SOD}-\mathrm{Ag}^{+}$was significantly lower than that of $\mathrm{Ag}^{+}$, indicating that the $\mathrm{SOD}-\mathrm{Ag}^{+}$system became more uniform without increasing the particle size. The RLS intensity of AgNPs was strong and the RLS intensity of SOD at $408 \mathrm{~nm}$ was weak. The RLS intensity of AgNPs-SOD was higher than that of AgNPs, indicating that polymerization occurred between AgNPs and SOD and increased the average particle diameter.

The results of resonance light scattering studies are shown in Table 1 . The above results were consistent with the difference that $\mathrm{Ag}^{+}$(AgNPs) had the stronger inhibitory effect on CAT (SOD) activity than AgNPs $\left(\mathrm{Ag}^{+}\right)$, indicating that the aggregation state and dispersion size were two key factors influencing the activity of CAT/SOD during the direct interaction between molecules.

\section{Influences of $\mathrm{AgNPs}$ and $\mathrm{Ag}^{+}$on protein structures of CAT/ SOD}

Most proteins have two absorption peaks at $205 \mathrm{~nm}$ and $280 \mathrm{~nm}$ respectively corresponding to peptide skeleton and the aromatic ring amino acids [64-66]. With the increase in AgNPs or $\mathrm{Ag}^{+}$concentration, the skeleton absorption peak of CAT and SOD decreased (Fig. 7). The results showed that both AgNPs and $\mathrm{Ag}^{+}$changed the protein skeleton of enzyme molecules, thus loosening the skeleton structure, unfolding the polypeptide chain, and gradually exposing the amino acids in the molecules. 

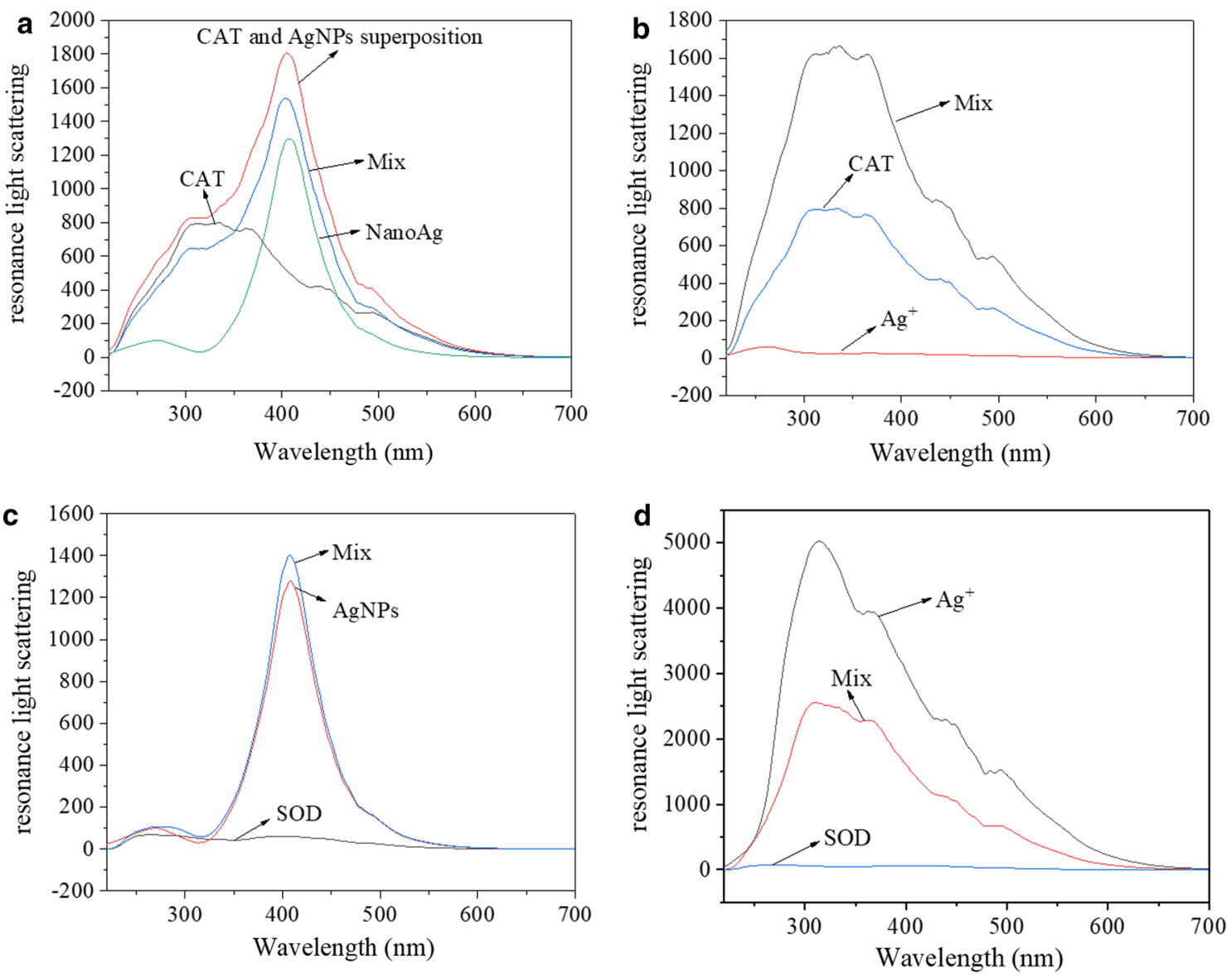

Fig. 6 Resonance light scattering spectra of AgNPs $(\mathbf{a}, \mathbf{c}) / \mathrm{Ag}^{+}(\mathbf{b}, \mathbf{d})$ and/or CAT (a, b)/SOD (c, d). Condition: T=298 K; $\mathrm{pH} 7.4 ; \lambda_{e x}=\lambda_{e m}=220 \mathrm{~nm} ; \mathbf{a}$ b Mix: $C(C A T)=5 \times 10^{-7} \mathrm{~mol} / \mathrm{L}, \mathrm{C}\left(\mathrm{AgNPs} / \mathrm{Ag}^{+}\right)=8 \times 10^{-7} \mathrm{~g} / \mathrm{mL} ; \mathrm{CAT}: \mathrm{C}(\mathrm{CAT})=5 \times 10^{-7} \mathrm{~mol} / \mathrm{L} ; \mathrm{AgNPs} / \mathrm{Ag}^{+}: \mathrm{C}\left(\mathrm{AgNPs} / \mathrm{Ag}^{+}\right)=8 \times 10^{-7} \mathrm{~g} / \mathrm{mL} ; \mathbf{c}, \mathbf{d} \mathrm{Mix}:$ $C(S O D)=6 \times 10^{-6} \mathrm{~mol} / \mathrm{L}, C\left(\right.$ AgNPs $\left./ \mathrm{Ag}^{+}\right)=8 \times 10^{-6} \mathrm{~g} / \mathrm{mL} ; \mathrm{SOD}: \mathrm{C}(\mathrm{SOD})=6 \times 10^{-6} \mathrm{~mol} / \mathrm{L} ; \mathrm{AgNPs} / \mathrm{Ag}^{+}: \mathrm{C}\left(\mathrm{AgNPs} / \mathrm{Ag}^{+}\right)=8 \times 10^{-6} \mathrm{~g} / \mathrm{mL}$

The UV absorption spectra showed that the influences of $\mathrm{Ag}^{+}$on the skeleton structures of CAT and SOD were more significant than those of AgNPs (Fig. 7). These results indicated that the effect of AgNPs or $\mathrm{Ag}^{+}$on the protein skeleton was also one of the reasons for the change in CAT/SOD activity in the direct interaction between molecules.

\section{Conclusions}

In this work, we explored the toxicity of silver nanoparticles $(20 \mathrm{~nm})$ and silver ions to RBCs and antioxidant enzymes (CAT, SOD and GPX).

AgNPs and $\mathrm{Ag}^{+}$could affect the enzymatic and nonenzymatic antioxidant system of RBCs. CAT, SOD and GPX were more sensitive to $\mathrm{Ag}^{+}$, whereas the RBCs had slightly higher GSH contents after the treatment with AgNPs. Both AgNPs and $\mathrm{Ag}^{+}$increased the MDA content of RBCs, but the difference between the effects of AgNPs and $\mathrm{Ag}^{+}$was not significant. We speculated that multiple factors, including the cell membrane penetration ability of AgNPs and $\mathrm{Ag}^{+}$, led to the results. The difference in the change in the enzyme activity indicated that $\mathrm{AgNPs}$ and $\mathrm{Ag}^{+}$might have different influencing mechanisms on CAT and GPX. And SOD has stronger resistance to both of AgNPs and $\mathrm{Ag}^{+}$.

The direct interaction among molecules (AgNPs/ $\mathrm{Ag}^{+}$and CAT/SOD) was one of the important reasons for the change in the antioxidant enzyme activity in the exposure at cell level. The spectral analysis results showed that the interaction mechanism and conformational changes were also the important factors for

Table 1 Aggregation state of AgNPs and $\mathrm{Ag}^{+}$with CAT/ SOD

\begin{tabular}{lll}
\hline & CAT & SOD \\
\hline AgNPs & More homogenous & Occurred polymerization \\
$\mathrm{Ag}^{+}$ & Occurred polymerization & More homogenous \\
\hline
\end{tabular}



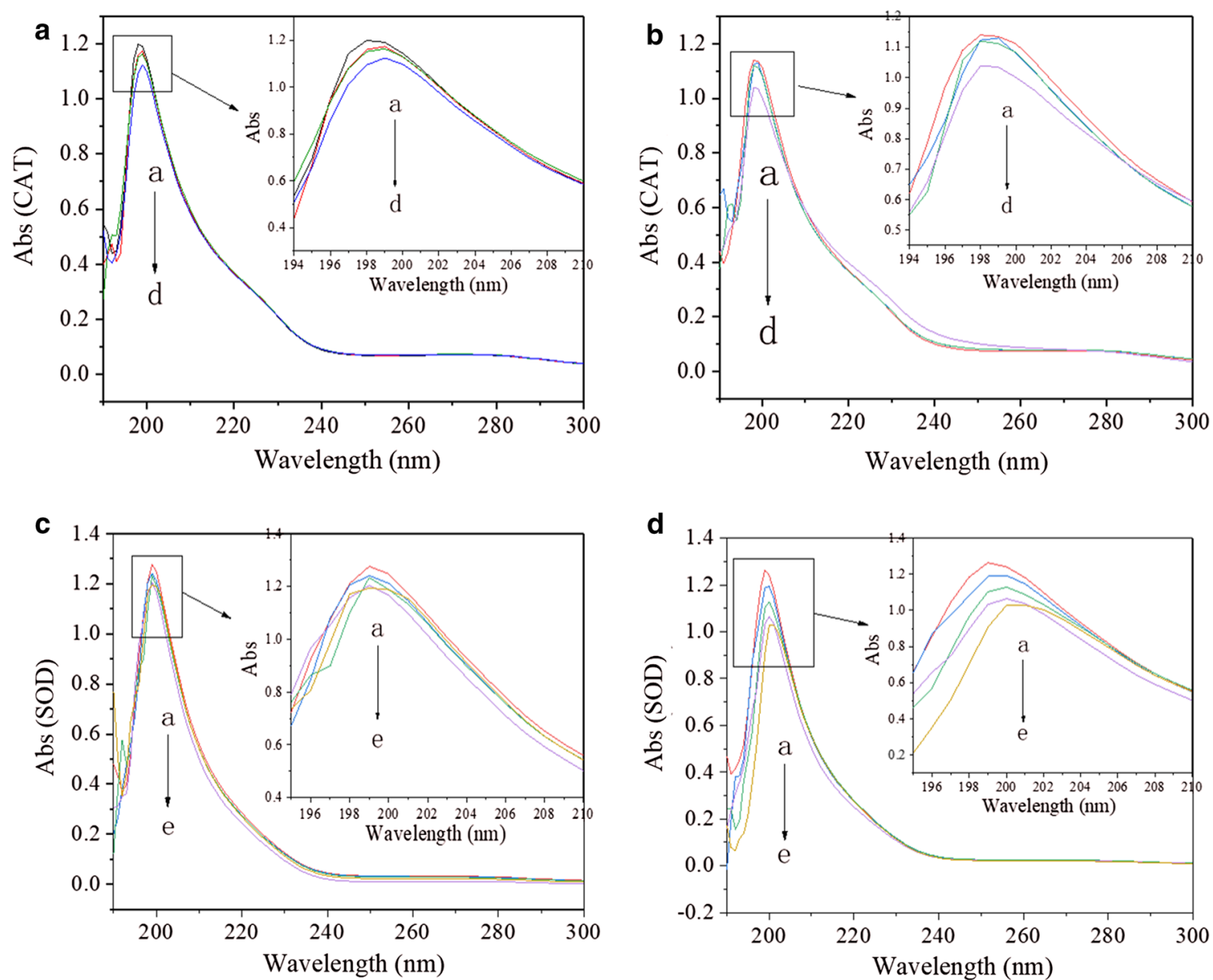

Fig. 7 The absorption spectra of CAT $(\mathbf{a}, \mathbf{b})$ and $\mathrm{SOD}(\mathbf{c}, \mathbf{d})$ in the presence of $\operatorname{AgNPs}(\mathbf{a}, \mathbf{c}) \mathrm{or} \mathrm{Ag}^{+}(\mathbf{b}, \mathbf{d})$ at different concentrations. Condition: $\mathrm{T}=298 \mathrm{~K} ; \mathrm{pH} 7.4 ; \mathbf{a}, \mathbf{b} \mathrm{C}(\mathrm{CAT})=5 \times 10^{-7} \mathrm{~mol} / \mathrm{L} ; \mathrm{C}\left(\mathrm{AgNPs} / \mathrm{Ag}^{+}, \times 10^{-6} \mathrm{~g} / \mathrm{mL}\right), \mathrm{a}-\mathrm{d}: 0.2,0.4,0.6,0.8 ; \mathbf{c}, \mathbf{d} \mathrm{C}(\mathrm{SOD})=5 \times 10^{-7} \mathrm{~mol} / \mathrm{L} ; \mathrm{C}\left(\mathrm{AgNPs} / \mathrm{Ag}^{+}\right.$, $\left.\times 10^{-6} \mathrm{~g} / \mathrm{mL}\right), a-e: 2,4,6,8,10$

the changes in the enzyme activity when enzyme proteins at the molecular level were directly exposed to the AgNPs or $\mathrm{Ag}^{+}$.

\section{Abbreviations}

RBCs: red blood cells; CAT: catalase; AgNPs: silver nanoparticles; SOD: superoxide dismutase; GPX: glutathione peroxidase; GSH: glutathione; MDA: malondialdehyde; ROS: reactive oxygen species; SD: standard deviation; PBS: phosphate-buffered saline; RLS: resonance light scattering; Trp: tryptophan; Tyr: tyrosine; Phe: phenylalanine.

\section{Acknowledgements}

This work has been supported by The National Natural Science Foundation of China (21707026), and The Guangzhou Key Laboratory of Environmental Exposure and Health (No. GZKLEEH201613).

\section{Authors' contributions}

ZC organized the study. WF, QZ and XZ performed the experiments. WF, ZC and WL analyzed the data. WF wrote the manuscript. ZC and WL edited the manuscript. All authors read and approved the final manuscript.
Availability of data and materials

The datasets used and/or analysed during the current study are available from the corresponding author on reason able request.

\section{Ethics approval and consent to participate}

The study was approved by the Ethics Committee of Weihai Blood Centre.

\section{Consent for publication}

Not applicable.

\section{Competing interests}

The authors declare that they have no competing interests.

\section{Author details}

${ }^{1}$ Department of Environmental Engineering, Harbin Institute of Technology, Weihai, 2\# Wenhua West Road, Weihai 264209, People's Republic of China.

${ }^{2}$ Guangzhou Key Laboratory of Environmental Exposure and Health, School of Environment, Jinan University, Guangzhou 510632, People's Republic of China. ${ }^{3}$ State Key Laboratory of Urban Water Resource and Environment, School of Environment, Harbin Institute of Technology, Harbin 150090, People's Republic of China. 
Received: 19 February 2019 Accepted: 9 May 2019

Published online: 17 May 2019

\section{References}

1. Han X, Zeng X, Zhang J, Huan H, Wang J, Foster NR, et al. Synthesis of transparent dispersion of monodispersed silver nanoparticles with excellent conductive performance using high-gravity technology. Chem Eng J. 2016;296:182-90.

2. Franci G, Falanga A, Galdiero S, Palomba L, Rai M, Morelli G, et al. Silver nanoparticles as potential antibacterial agents. Molecules. 2015;20:8856-74.

3. Gonzalez C, Rosas-Hernandez H, Ramirez-Lee MA, Salazar-García S, Ali SF Role of silver nanoparticles (AgNPs) on the cardiovascular system. Arch Toxicol. 2016:90:1-19.

4. Robertson TA, Sanchez WY, Roberts MS. Are commercially available nanoparticles safe when applied to the skin? J Biomed Nanotechnol. 2010;6:452-68.

5. Martin JD, Colson TL, Langlois VS, Metcalfe CD. Biomarkers of exposure to nanosilver and silver accumulation in yellow perch (Perca flavescens). Environ Toxicol Chem. 2016:36:1211-20.

6. Nabinejad AR, Noaman V, Nekouiee MK. Evaluation of silver residues accumulation in tissues of broilers treated with nanosilver using MNSR (a clinical trial). Arch Razi Inst. 2016;71:51-5.

7. Rani PU, Yasur J, Loke KS, Dutta D. Effect of synthetic and biosynthesized silver nanoparticles on growth, physiology and oxidative stress of water hyacinth: Eichhornia crassipes (Mart) Solms. Acta Physiol Plant. 2016;38:58.

8. Cambier S, Røgeberg M, Georgantzopoulou A, Serchi T, Karlsson C, Verhaegen $S$, et al. Fate and effects of silver nanoparticles on early life-stage development of zebrafish (Danio rerio) in comparison to silver nitrate. Sci Total Environ. 2018;610-611:972-82.

9. Choi Y, Kim HA, Kim KW, Lee BT. Comparative toxicity of silver nanoparticles and silver ions to Escherichia coli. J Environ Sci. 2018;66:50-60.

10. Ahamed M, Alsalhi MS, Siddiqui MKJ. Silver nanoparticle applications and human health. Clin Chim Acta. 2010;411:1841-8.

11. Vazquez-Muñoz R, Borrego B, Juárez-Moreno K, García-García M, Morales JDM, Bogdanchikova N, et al. Toxicity of silver nanoparticles in biological systems: does the complexity of biological systems matter? Toxicol Lett. 2016;259:S190-1.

12. Seung-Heon S, Mi-Kyung Y, Hae-Sic K, Hyung-Suk K. The effects of nanosilver on the proliferation and cytokine expression by peripheral blood mononuclear cells. Int Immunopharmacol. 2007;7:1813-8.

13. Greulich C, Kittler S, Epple M, Muhr G, Köller M. Studies on the biocompatibility and the interaction of silver nanoparticles with human mesenchymal stem cells (hMSCs). Langenbecks Arch Surg. 2009:394:495-502.

14. Kim HR, Mi JK, Lee SY, Oh SM, Chung KH. Genotoxic effects of silver nanoparticles stimulated by oxidative stress in human normal bronchial epithelial (BEAS-2B) cells. Mutat Res. 2011;726:129-35.

15. Jian C. Effects of different doses of nano silver on vascular endothelial cell proliferation in vitro. Chin J Cell Mol Immunol. 2011:27:697-9.

16. Braydich-Stolle LK, Lucas B, Schrand A, Murdock RC, Lee T, Schlager JJ, et al. Silver nanoparticles disrupt GDNF/Fyn kinase signaling in spermatogonial stem cells. Toxicol Sci. 2010;116:577-89.

17. Syed A, Saraswati S, Kundu GC, Ahmad A. Biological synthesis of silver nanoparticles using the fungus Humicola sp. and evaluation of their cytoxicity using normal and cancer cell lines. Spectrochim Acta A Mol Biomol Spectrosc. 2013;114:144-7.

18. Lara HH, Ayalanuñez NV, Ixtepanturrent L, Rodriguezpadilla C. Mode of antiviral action of silver nanoparticles against HIV-1. J Nanobiotechnol. 2010;8:1.

19. Ale A, Bacchetta C, Rossi AS, Galdopórpora J, Desimone MF, Torre FRDL, et al. Nanosilver toxicity in gills of a neotropical fish: metal accumulation, oxidative stress, histopathology and other physiological effects. Ecotoxicol Environ Saf. 2018;148:976-84.

20. Choi JE, Kim S, Ahn JH, Youn P, Kang JS, Park K, et al. Induction of oxidative stress and apoptosis by silver nanoparticles in the liver of adult zebrafish. Aquat Toxicol. 2010;100:151-9.

21. Orbea A, González-Soto N, Lacave JM, Barrio I, Cajaraville MP. Developmental and reproductive toxicity of PVP/PEI-coated silver nanoparticles to zebrafish. Comp Biochem Physiol C Toxicol Pharmacol. 2017;199:59-68.
22. Castellini C, Ruggeri S, Mattioli S, Bernardini G, Macchioni L, Moretti E, et al. Long-term effects of silver nanoparticles on reproductive activity of rabbit buck. Syst Biol Reprod Med. 2014;60:143-50.

23. Johari SA, Sarkheil M, Behzadi M, Veisi S. Influence of salinity on the toxicity of silver nanoparticles (AgNPs) and silver nitrate $\left(\mathrm{AgNO}_{3}\right)$ in halophilic microalgae, Dunaliella salina. Chemosphere. 2018;209:156-62.

24. Malysheva A, Voelcker N, Holm PE, Lombi E. Unraveling the complex behavior of AgNPs driving NP-cell interactions and toxicity to algal cells. Environ Sci Technol. 2016:50:12455-63.

25. Qian H, Peng X, Han X, Ren J, Sun L, Fu Z. Comparison of the toxicity of silver nanoparticles and silver ions on the growth of terrestrial plant model Arabidopsis thaliana. J Environ Sci. 2013;25:1947-56.

26. Naomi L. Nanosilver toxicity: ions, nanoparticles-or both? Environ Sci Technol. 2008:42:8617

27. Durán N, Durán M, Jesus MBD, Seabra AB, Fávaro WJ, Nakazato G. Silver nanoparticles: a new view on mechanistic aspects on antimicrobial activity. Nanomed Nanotechnol Biol Med. 2016;12:789-99.

28. Candida V, Guido D, Elisabetta O, Fabrizio DM, Ilaria B, Milena M, et al. Phytotoxic and genotoxic effects of silver nanoparticles exposure on germinating wheat seedlings. J Plant Physiol. 2014;171:1142-8.

29. Greulich C, Braun D, Peetsch A, Diendorf J, Siebers B, Epple M, et al. The toxic effect of silver ions and silver nanoparticles towards bacteria and human cells occurs in the same concentration range. RSC Adv. 2012:2:6981-7.

30. Masoumi S, Jamili S, Niknejad H, Mashinchian Moradi A. Toxic effects of nanosilver on red blood cells (RBC) and liver tissue of common carp (Cyprinus carpio). J Anim Environ. 2015;6:177-85.

31. Heydrnejad MS, Samani RJ, Aghaeivanda S. Toxic effects of silver nanoparticles on liver and some hematological parameters in male and female mice (Mus musculus). Biol Trace Elem Res. 2015;165:1-6.

32. Jong WHD, Ven LTMVD, Sleijffers A, Park MVDZ, Jansen EHJM, Loveren $H \mathrm{~V}$, et al. Systemic and immunotoxicity of silver nanoparticles in an intravenous 28 days repeated dose toxicity study in rats. Biomaterials. 2013;34:8333-43.

33. Aghababa H, Amirkhani-Dehkordi S, Naghsh N. Investigating nanosilver effects on blood cells counter in male rats. J Shahid Sadoughi Univ Med Sci. 2013;20:716-23.

34. Kummara S, Patil MB, Uriah T. Synthesis, characterization, biocompatible and anticancer activity of green and chemically synthesized silver nanoparticles - a comparative study. Biomed Pharmacother. 2016;84:10-21.

35. Chen L, Fang L, Ling J, Ding C, Kang B, Huang C. Nanotoxicity of silver nanoparticles to red blood cells: size dependent adsorption, uptake, and hemolytic activity. Chem Res Toxicol. 2015;28:501-9.

36. Angelo D, Pier Giorgio R, Lello Z. The red blood cell proteome and interactome: an update. J Proteome Res. 2010:9:144-63.

37. Awasthi YC, Beutler E, Srivastava SK. Purification and properties of human erythrocyte glutathione peroxidase. J Biol Chem. 1975:250:5144-9.

38. Chi Z, Tan S, Li W, Wen Z, Song X, Wang M. In vitro cytotoxicity of decabrominated diphenyl ether (PBDE-209) to human red blood cells (hRBCs). Chemosphere. 2017;180:312-6.

39. Pasternack $R$, Collings PJ. Resonance light scattering: a new technique for studying chromophore aggregation. Science. 1995;269:935-9.

40. Campos H, Brandao LC, D'Almeida V, Grego BHC, Bittencourt LR, Tufik S, et al. Sleep disturbances, oxidative stress and cardiovascular risk parameters in postmenopausal women complaining of insomnia. Climacteric. 2006:9:312-9.

41. Mecocci P, Polidori MC, Troiano L, Cherubini A, Cecchetti R, Pini G, et al. Plasma antioxidants and longevity: a study on healthy centenarians. Free Radic Biol Med. 2000;28:1243-8.

42. Herken H, Uz E, Ozyurt H, Söğüt S, Virit O, Akyol O. Evidence that the activities of erythrocyte free radical scavenging enzymes and the products of lipid peroxidation are increased in different forms of schizophrenia. Mol Psychiatry. 2000;6:66-73.

43. Ondrej G, Ivana B, Lubomír R. Interaction of metal ions with biomolecular ligands: how accurate are calculated free energies associated with metal ion complexation? J Phys Chem A. 2011;115:11394-402.

44. Yuan T, Fan W, Cong Y, Xu H, Li C, Meng J, et al. Linoleic acid induces red blood cells and hemoglobin damage via oxidative mechanism. Int J Clin Exp Pathol. 2015:8:5044-52. 
45. Van't Erve T, Doskey C, Wagner B, Hess J, Darbro B, Ryckman K, et al. The heritability of glutathione and related metabolites in stored red blood cells. Free Radic Biol Med. 2014;76:107-13.

46. Zhang R, Zhang $X$, Gao S, Liu R. Assessing the in vitro and in vivo toxicity of ultrafine carbon black to mouse liver. Sci Total Environ. 2019;655:1334-41.

47. Sies H. Oxidative stress: a concept in redox biology and medicine. Redox Biol. 2015;4:180-3.

48. Peters T Jr. All about albumin. Biochemistry, genetics and medical application. London: Academic press; 1995.

49. Quinlan G, Martin G, Evans T. Albumin: biochemical properties and therapeutic potential. Hepatology. 2005;41:1211-9.

50. Kuznetsova IM, Stepanenko OV, Turoverov KK, Staiano M, Scognamiglio V, Rossi M, D'Auria S. Fluorescence properties of glutamine-binding protein from Escherichia coli and its complex with glutamine. J Proteome Res. 2005:4:417-23.

51. Roy S. An insight of binding interaction between Tryptophan, Tyrosine and Phenylalanine separately with green gold nanoparticles by fluorescence quenching method. Optik. 2017;138:280-8.

52. Tang J, Feng $L$, Chen $X$. Binding analysis of glycyrrhetinic acid to human serum albumin: fluorescence spectroscopy, FTIR, and molecular modeling. Bioorg Med Chem. 2006;14:3210-7.

53. Yue Y, Chen X, Qin J, Yao X. A study of the binding of C.I. Direct Yellow 9 to human serum albumin using optical spectroscopy and molecular modeling. Dyes Pigments. 2008;79:176-82.

54. Zhang B, Yu L, Zhang R, Liu Y, Liu R. Investigation on the interaction of nanoAg with Cu-Zn SOD. Luminescence. 2016;30:1195-200.

55. Zhang B, Zhai W, Liu R, Yu Z, Shen H, Hu X. Evaluation on the toxic effects of NanoAg to catalase. J Nanosci Nanotechnol. 2015;15:1473-9.

56. Chen RF. Fluorescence quenching due to mercuric ion interaction with aromatic amino acids and proteins. Arch Biochem Biophys. 1971;142:552-64.

57. Zhao X, Liu R, Teng Y, Liu X. The interaction between $\mathrm{Ag}^{+}$and bovine serum albumin: a spectroscopic investigation. Sci Total Environ. 2011;409:892-7.
58. Miller JN. Recent advances in molecular luminescence analysis. Proc Anal Div Chem Soc. 1979;16:203-8.

59. Inman EL, Winefordner JD. Constant energy synchronous fluorescence for analysis of polynuclear aromatic hydrocarbon mixtures. Anal Chem. 1982;54:2018-22.

60. Wu X, Zhou J, Gu X, Wei S, Feng Y, Lu T, et al. Study on interaction between hypocrellin A and hemoglobin or myoglobin using synchronous fluorescence spectra. Spectrosc Spectr Anal. 2006;26:2287-90.

61. Riva BSVDL, Costa-Fernández JM, Pereiro R, Sanz-Medel A. Spectrafluorimetric method for the rapid screening of toxic heavy metals in water samples. Anal Chim Acta. 2002:451:203-10.

62. Zhao X, Lu D, Liu QS, Li Y, Feng R, Hao F, et al. Hematological effects of gold nanorods on erythrocytes: hemolysis and hemoglobin conformational and functional changes. Adv Sci. 2017;4:1700296.

63. Liu B, Yang C, Yan X, Wang J, Lv Y. Interaction of avelox with bovine serum albumin and effect of the coexistent drugs on the reaction. Int J Anal Chem. 2012;2012:408057.

64. Zhu Y, Wu F, Lin Y. Quantitative analysis of protein concentration by absorption peak integration method of UV spectroscopy-taking alkaline phosphatase as an example. Spectrosc Spectr Anal. 2013;33:1845-9.

65. Yang B, Hao F, Li J, Chen D, Liu R. Binding of chrysoidine to catalase: spectroscopy, isothermal titration calorimetry and molecular docking studies. J Photochem Photobiol B. 2013;128C:35-42.

66. Saidel $\sqcup$. Ultraviolet absorption spectra of peptides. I. Compounds containing a single monoalkyl-substituted amide link. Arch Biochem Biophys. 1955;54:184-200

\section{Publisher's Note}

Springer Nature remains neutral with regard to jurisdictional claims in published maps and institutional affiliations.
Ready to submit your research? Choose BMC and benefit from:

- fast, convenient online submission

- thorough peer review by experienced researchers in your field

- rapid publication on acceptance

- support for research data, including large and complex data types

- gold Open Access which fosters wider collaboration and increased citations

- maximum visibility for your research: over 100M website views per year

At BMC, research is always in progress.

Learn more biomedcentral.com/submissions 